\title{
Academic Lives Lived Outside
}

\author{
Fiona Whelan (Queen Mary University of London)
}

What does it mean to be an academic? What is the perception of who or what an academic is? These are questions pondered by those who live their lives outside the academy but view themselves as academics. They are underlined by harmful attitudes which seek to situate an academic within and only within the academy. Can you be an academic if you work outside of an academic institution? Do those academic institutions treat all academics the same?

In an environment where the majority of $\mathrm{PhD}$ graduates do not get an academic job, these questions are more pertinent than ever. ${ }^{1}$ Where do these graduates go and what are their identities? Many still are actively engaged in research and producing world-leading publications. Some do this in the hope of eventually securing that pot at the end of the rainbow - the gloried academic job. Some do not want an academic job but want to continue to engage in research in their own time (I fit squarely into that category). You might read this and think "What is the big deal, surely if you engage in academic research then you are an academic?" Perhaps, or perhaps not.

The Oxford English Dictionary sums up this quandary when defining the noun 'academic':

"A member of a university or college, now spec. a senior member, a member of a university or college's teaching or research staff. Also in weakened sense: a person interested in or excelling at pursuits involving reading, thinking, and study. “2

By this definition, those who pursue academic interests without academic affiliation or without an academic job title are not really academics in the purest sense. The definition itself implies a two-tiered system. There are 'proper' academics who work in a university in a research or lecturing role, and those in a 'weakened sense' who are interested or excel in academic pursuits but are outside the true academic pale of the hallowed university halls. This includes independent researchers like me who do not hold an academic title but actively pursue top-level academic research, present at academic conferences and publish within academic press.

You might now think that my reading of this is too black and white - that there are academics who work outside of ivory towers who we would rightly call academics.
Museum and gallery curators, field archaeologists and literary critics have all been sold to me as evidence that the academy is welcoming to those beyond the narrow titles of lecturer, reader and professor. Yet there are so many more that we exclude and ignore.

Admittedly, this is a reflective piece based on my experience. Following completion of my doctoral studies, I chose to go into a professional services career within universities. This left me in limbo: still working within the academic milieu but no longer part of it. This tension led me to strive to become a voice for those of us who are still academics but simply do not get paid for our academic work. 'Leaving' academia for a non-academic career has not suddenly rid me of the identity I held for the previous five years. Since I 'left' academia I have been more academically prolific than before: two books have been published and one article, with another pending, three conferences have been attended and there are invites to more.

To pause for a moment and think about the term 'nonacademic'. I can think of few other industries where we describe a swathe of workers by what they are not. There are academics and everyone else is a 'non-academic'. You are literally perceived in the negative. You are contrasted with academics and found lacking; lesser, lower. It creates an 'us and them' environment. Administrators and managers in the National Health Service in the UK are not called 'non-doctors', clerks in law firms are not called 'non-lawyers'. I am being facetious of course, but the point is made, I hope. While 'us and them' tensions do exist within the medical profession, for example, they have not explicitly made up a term to both create and then further such a divide. Within academic institutions we have allowed a two-tier hierarchy to develop whereby no respect is accorded to the administration of a university. No respect is given to the literal functions that make an institution run in today's world: admissions, student records, graduation, finance, HR, marketing, student support, library services, estates services and so much more. In respecting the role of academics in teaching, learning and research, we have gone so far as to accept being viewed in opposition to them. Many academics I have spoken to didn't know how offensive it is to be referred to in the negative; how demeaning and demoralizing it can be. Most change their language once the realization strikes. Now imagine you are in my 
position. I am an academic - I stand by that because although I work outside of traditional academia, I still pursue research and actively publish. Imagine sitting in a meeting with someone with the same credentials as you BA, MA, PhD - with the same output as you and they call you a 'non-academic' because of your job title, this is challenging. Academic lives lived on the outside are fraught when you are constantly reminded that you are not really part of the club, or at least not its inner sanctum.

To return to the question of leaving academia, I am being pointedly deliberate in the way I describe it since many leave academic structures, not academic life. Equally, many did not leave but were forced out. Structural inequalities, a hyper-competitive job market, favouritism, ageism, elitism and disability are just some of the things which close the gates to the ivory towers. For those who get in those gates with junior research fellowships and early career researcher positions, and for those that have known no life beyond those gates, please do not make assumptions and cast aspersions on those who are no longer in the academic fold or who have stopped trying. I have heard academic colleagues joke about management in universities being 'failed academics'. The irony is that my research output often exceeds those who joke about 'failed academics' because to them my identity relates solely to my 'non-academic' job title. I have also heard on social media the argument that those who left were not committed enough, they gave up too soon and did not have the stamina to stay on the early career researcher hamster-wheel until the magic permanent or tenured job came through. These are pernicious assumptions which place the blame on the individual rather than on the realities of the academic job market.

Let us consider some of these issues which can only be known and felt by those on the outside looking in. The longer you are out, the harder it is to get back in. Many ECR fellowships are time-limited from $\mathrm{PhD}$ completion meaning that if you need time post- $\mathrm{PhD}$, there are diminishing opportunities to return. This is most striking for people with family or caring responsibilities, disabilities, and for those who need a job, any job, immediately post-PhD to secure a visa to remain in the country they studied. Precarity is a word often associated with those in the early stages of their academic career. ${ }^{3}$

Academic precarity, in my interpretation, applies to those who have to uproot themselves every 9-12 months for another fixed-term, low-paid contract; those who live pay check to pay check in pursuit of their dreams; those who cannot put down roots with family and friends because of uncertainty around where the next job will come from; those for whom home ownership is out of the question, a pipe-dream. These are some of the very real reasons that I chose not to participate in the academic mill. Precarity can also apply to those on the outside, actively trying to get back in but finding themselves unsuccessful or not quite ready for a comeback. As the years tick by, the door to returning closes. To those already on the inside, with the support networks or financial means to allow them to pursue that early career trajectory, I offer a word of caution: consider your use of the term 'precarity'. I understand the anxiety or concern around getting the next job, producing the next output and getting that permanent position. Yet there are academics who are in a truly precarious position, working two or three jobs just to pay the bills, those whose students in an afternoon lecture may later catch sight of them working in a supermarket. ${ }^{4}$ Equally, there are academics who never even had the opportunities you did, some who saw their chance drift away without ever getting a foot on even the bottom rung.

Social media is both a blessing and a curse as an academic on the outside. On the one hand, the formerly insular academic world is now open and receptive. It is easy to make connections, find opportunities, remain engaged with your research and feel that you are still part of that academic community. Yet, social media can make you feel excluded and can highlight the distinctions between perceived real academics and those playing as them on the outside. There is a performative element to academic social media, meaning a need to put everything out there about how great or how challenging academia is. There is a constant reminder of the opportunities available to those with institutional affiliation which is most striking around spring and summer when academic jobs and research grants are announced. Furthermore, there is resentment towards those who complain about aspects of their jobs, whether that is teaching or doing the required administration associated with teaching and research. While I do believe that it is important to be aware of the realities of academic jobs, the tone in which this information is conveyed is often critical. For every ECR or lecturer who complains repeatedly about their job, there are tens, if not hundreds, of equally qualified individuals who would happily take their spot. When we know that only a minority of $\mathrm{PhD}$ graduates will get an academic job, it is imperative that we are sensitive to the feelings of the majority.

As an academic who works in university administration, the tension has been even more pronounced. As already noted, I have been perceived as a 'failed academic' and called a 'non-academic', bolstering a two-tier hierarchy between academics and 'the rest'. Social media has exacerbated this as I follow many academics who occasionally deride professional services and administration. Wearing two hats, as I do, I try to stand up for my career identity and as a result have been called a 'foot soldier', been told to shut up and much worse. It is interesting to me that people can engage and respect me 
when I wear my academic hat, but get defensive when I wear my other, 'non-academic' hat; then I am lesser, I can be talked down to, I should know my place.

The goal of my blog Beyond the Doctorate ${ }^{5}$ was to shine a light on the experiences of $\mathrm{PhD}$ graduates facing an uncertain world. With so few opportunities to pursue a traditional academic career, many will forge an alternative academic life. For me, this means a career in university management while pursuing academic research in my spare time. This requires sacrifice in terms of time with friends and family and money, as I have no access to funding to attend conferences and engage in vital networking. When you are on the outside, maintaining contacts is challenging yet critical. I seek to be realistic to graduates about what careers on the outside will feel like; that you often have to subjugate your academic identity or leave that hat at the front door because colleagues may not know or care about your background; that opportunities and interesting careers abound when we widen our search but that this does not mean we are 'failed academics'.

We are academics. My academic identity does not rely on my job title, it relies on my credentials, the quality of my research and the calibre of my output. In a world where academic opportunities are stagnating and the number of $\mathrm{PhD}$ graduates is ballooning, we must broaden our interpretation of what an academic is and welcome greater numbers of people into the academic fold.

\footnotetext{
${ }^{1}$ See HESA data from 2008 which saw that 9.2\% were working in Higher Education research occupations, $21.6 \%$ were teaching or lecturing in Higher Education:

https://www.vitae.ac.uk/doing-research/are-you-thinking-of-doing-a-phd/what-do-doctoral-graduates-do

For a US context, see:

https://www.insidehighered.com/news/2017/08/28/more-humanities-phds-are-awarded-job-openings-are-disappearing Accessed 30 October 2018.

2 See http://www.oed.com/view/Entry/880;jsessionid=24F245E90CC33AAD8C5C34D117B3A768 Accessed 30 October 2018.

${ }^{3}$ See for example http://allegralaboratory.net/unravelling-academic-precarity-universitycrisis Accessed 30 October 2018. See also, https://blog.jobs.ac.uk/post-phd-life/way-out-of-precarity/ Accessed 30 October 2018.

${ }^{4}$ https:/www.theguardian.com/commentisfree/2015/jun/22/adjunct-professor-earn-less-than-pet-sitter Accessed 30 October 2018.

${ }^{5}$ http://beyondthedoctorate.blogspot.com/
}

\section{Recommended Citation}

Whelan, F. (2018). Academic Lives Lived Outside. On Education. Journal for Research and Debate, 1 (3). https://doi.org/10.17899/on_ed.2018.3.2

\section{About the Author}

Fiona Whelan completed her DPhil in Medieval History at the University of Oxford in 2015, and has previously studied at Trinity College Dublin and University College London. She has published widely on medieval codes of behaviour and early courtesy literature. She is currently pursuing a career in alternative academia, working in Higher Education management in London. 